\title{
Genotyping of avian infectious bronchitis virus in broiler farms in Duhok province, north of Iraq
}

\author{
R.H. Isa ${ }^{1}$, J.M. Abdo ${ }^{2}$, and Y.M. Al-Barzinji ${ }^{3 \oplus}$ \\ ${ }^{1}$ Animal Production Department, College of Agricultural Engineering Sciences, ${ }^{2}$ College of Pharmacy, University of Duhok, \\ Duhok, ${ }^{3}$ Animal Resources Department, College of Agricultural Engineering Sciences, Salahaddin University, Erbil, Iraq
}

\section{Article information \\ Article history: \\ Received February 28, 2021 \\ Accepted May 20, 2021 \\ Available online November 23, 2021}

\section{Keywords:}

Broiler

Infectious bronchitis

Duhok

Iraq

Nested RT-PCR

\section{Correspondence:}

R.H. Isa

renas_kurd2003@uod.ac

\begin{abstract}
Infectious bronchitis disease is becoming the most challenging disease in broiler fields in Iraq. This disease leads to massive economic loss every round of production. Three vaccine strains H120, Ma5, and 4/91 are used to combat the disease during the production period while outbreaks occur continuously. This study aimed to investigates the prevalence and circulation of Mass and 4/91 IBV strains in the broiler fields in Duhok province which is the first record in the area. Positive samples were obtained from suspected flocks to this disease during 2018-2020. A specific region of S1 was amplified using specific pairs of primers. Genotyping was performed by nested PCR using specified primers for detecting both Mass and 4/91 strains. In the results, all of the positive flocks were infected with nephropathogenic strain 793/B or 4/91. Two of the positive flocks had an infection with both Mass and 4/91. These results indicate that more than one strain circulates in the area as well as shows the weakness of vaccines used in broiler fields.
\end{abstract}

DOI: 10.33899/ijvs.2021.129635.1670, (CAuthors, 2022, College of Veterinary Medicine, University of Mosul.

This is an open access article under the CC BY 4.0 license (http://creativecommons.org/licenses/by/4.0/).

\section{Introduction}

Avian Infectious bronchitis disease (IB) is one of the most challenging diseases in the poultry industry. Chicken is exposed to IBV through its entire lifespan (1). Massive economic loss is due to the fast and rises emergence of novel variants or serotypes in both broiler and layer flocks (2). Morbidity reaches $100 \%$ with a mortality of $20-30 \%$ (3) while secondary infection may increase flock mortality (4). Moreover, the upper respiratory tract, kidney, digestive tract, and ovary are the main infection sites of this virus. Clinical symptoms are difficulty in breathing, plaque in the trachea and/or bifurcation, ovary damage, kidney swelling, and sneezing (2). The main consequences are weight loss, drop in egg production, and mortality (1). Although no vertical transmission has been claimed (5), it is transmitted horizontally such as direct and indirect chicken contact and air-born route (contamination and poor field biosecurity). Although successful vaccination is considered one of the best methods for immunizing the birds from this disease, genotyping the field strain may determine the vaccine strains that should be applied (6). Genomic deletions, insertions, substitutions, point mutations, and RNA recombination of the $\mathrm{S} 1$ gene are associated with the emergence of new variants (7). The $\mathrm{S} 1$ is responsible for viral attachment to the host cell receptors. Additionally, there are three hypervariable regions in the structure of this gene. For these reasons, this gene has been the preferable region for genotyping this virus by many researchers (8). Different serotypes of newly evolved variants from chickens may cause partial or complete vaccination failure $(5,9)$. In Iraq, the first report on this disease was made by (10). Later, the isolation and identification were performed for a specific isolate AM 88 by (11). However, the use of three inactivated and/or live-attenuated IBV vaccines H120, Ma, and 4/91 couldn't stop the massive economic loss in the Iraqi poultry industry due to continuous outbreaks of this disease (12). In the south and middle of Iraq, studies on this disease have been performed to genotype this infection agent (13). The new variant, Sul/01/09 (GQ281656) has 
been detected in Sulaimani province, North of Iraq (14). However, In Duhok province, besides one study on virus detection (15), circulation of IBV strains in the broiler fields has not been documented yet. Therefore, this study aims to genotype the IB virus isolated from broiler fields in this area by Nested-PCR.

\section{Materials and methods}

\section{Sample collection}

A total of 180 trachea tissue samples (3 samples from each field) were obtained from 60 suspected broiler fields located in Duhok governorate, North of Iraq. The sample details were recorded during the collection. The tracheal tissue samples were transported in sterile tubes and kept on ice until RNA extraction.

\section{RNA extraction}

Total RNA was extracted within 24 hours from sample collection using QIAamp Viral RNA Mini Kit (Qiagen, Germany). A pool of three tracheas tissues was homogenized manually from each field. The RNA extraction was applied according to the procedure given by the manufacturer. NanoDrop 2000/2000 was used to measure RNA quality and quantity and saved at $-20^{\circ} \mathrm{C}$ for further downstream applications.

\section{Reverse transcription}

Reverse transcription was applied for cDNA synthesis using SuPrimeScript RT Premix Kit (GeNet Bio, South Korea). Briefly, about $500 \mathrm{ng} / \mu 1$ to $1 \mu \mathrm{g} / \mu \mathrm{l}$ of total RNA and 100 pmol of Random Hexamers were mixed with $10 \mu 1$ of ready-to-use RT mixture (2X) and adjusted to $20 \mu \mathrm{l}$ reaction with nuclease-free water. The cycling program was performed in GeneAmp PCR System 9700 (Applied Biosystems, Singapore). The sample was incubated at $25^{\circ} \mathrm{C}$ for 5 minutes then heated for 60 minutes at $50^{\circ} \mathrm{C}$ and finally, the reaction was stopped at $70^{\circ} \mathrm{C}$ for 10 minutes.

\section{Partial S1 gene amplification}

A region 464 bp located on the Hypervariable region 3 (HVR-3) of S1 gene of IBV was amplified by conventional PCR using HS Prime Taq Premix kit (GeNet Bio, South Korea) in GeneAmp PCR System 9700 (Applied Biosystems, Singapore). PCR reaction was made in a $20 \mu 1$ reaction volume containing $10 \mu \mathrm{l}$ HS Prime Taq Premix (2X), $2 \mu \mathrm{l}$ cDNA, $1 \mu \mathrm{l}$ of each reverse and forward primers $10 \mathrm{pmol}$ (Table 1) and reaction volume was adjusted to the desired volume using nuclease-free water. The cycling program was as follows; initial denaturation $94^{\circ} \mathrm{C}$ for 5 minutes followed by 35 cycles of denaturation $94^{\circ} \mathrm{C}$ for 30 seconds, annealing $50^{\circ} \mathrm{C}$ for 30 seconds, extension $72^{\circ} \mathrm{C}$ for 35 seconds and final extension $72^{\circ} \mathrm{C}$ for 2 minutes then cooled at $4^{\circ} \mathrm{C}$. Results were confirmed using a $1.5 \%$ agarose gel.

Amplified DNA (464 bp) from the first PCR round was used in Nested-PCR to detect specific amplicons of $154 \mathrm{bp}$ and $295 \mathrm{bp}$ for 4/91 and Mass serotypes, respectively. A total of $20 \mu \mathrm{l}$ reaction was prepared to contain $10 \mu \mathrm{l}$ of HS Prime Taq Premix (2X), $2 \mu$ l of the first-round PCR product, $1 \mu 1$ of forward primers BCE1+, MCE1+ Specific for 4/91 and Mass serotype, respectively and $1 \mu 1$ of reverse primer XCE3- (a universal primer for IBV) (Table 1), and volume was adjusted by adding nuclease-free water. Amplification was carried out in Ependrof AG Mastercycler (Hamburg, Germany) according to the following conditions; 1 cycle for Initial denaturation $94^{\circ} \mathrm{C}$ for 5 minutes followed by 35 cycles of denaturation $94^{\circ} \mathrm{C}$ for 30 seconds annealing $50^{\circ} \mathrm{C}$ for 35 seconds extension $72^{\circ} \mathrm{C}$ for 1 minute and final extension $72^{\circ} \mathrm{C}$ for 8 minutes then cooled at $4^{\circ} \mathrm{C}$. Results were visualized by $2 \%$ agarose gel.

Table 1: Primer sequences were used in both partial and nested-PCR reactions

\begin{tabular}{lccc}
\hline Oligonucleotide & Sequences & Band Size (bp) & Specificity \\
\hline XCE1+ & 5'-CACTGGTAATTTTTCAGATGG-3' & $464 \mathrm{bp}$ & Universal \\
XCE2- & 5'-CTCTATAAACACCCTTACA-3' & $295 \mathrm{bp}$ & Massachusetts \\
MCE1+ & 5'-AATACTACTTTTACGTTACAC-3' & $154 \mathrm{bp}$ & 793/B (4/91) \\
BCE1+ & 5'-AGTAGTTTTGTGTATAAACCA-3' & - & Universal \\
XCE3- & 5'-CAGATTGCTTACAACCACC-3' & - & . \\
\hline
\end{tabular}

\section{Results}

All the collected samples were having symptoms related to IBV such as gasping, nasal discharge, sneezing, difficulty in breathing. According to the information that was taken on the day of sample collection, five of the positive flocks were vaccinated with 4/91 and/or Ma5, two of them had Mass types of vaccine, however, the vaccination history for one of them was unknown. On the day of sample collection, all of these samples were having a mortality rate of around 1-2\% except in one field which was $8 \%$ (Table 2).

The viral extraction kit was efficient in isolating RNA from collected tissue samples with high quality and quantity. Primers (XCE1+ and XCE2-) were able to amplify 464 bp of IBV S1 gene from eight collected samples (Figure 1). 
In the second round of PCR (nested PCR), 154 bp was amplified in all positive samples indicating that all the fields were infected with 793/B (4/91) strain of IBV. Also, $295 \mathrm{bp}$ and $154 \mathrm{bp}$ were detectable in two samples (samples 2 and 6) which means that the fields were having coinfection with both IBV strains (Mass and 4/91) (Figure 2).

Table 2: Information of the positive samples to IB from broiler field in Duhok governorate

\begin{tabular}{lccc}
\hline Location & Age (D) & Mortality (\%) & Vaccination \\
\hline Duhok* & 29 & $1 \%$ & $4 / 91+$ Ma5 \\
Sumel & 23 & $<1 \%$ & $4 / 91$ \\
Amedi & 12 & $1 \%$ & $4 / 91$ \\
Bardarash & 24 & $<1 \%$ & $4 / 91+$ Ma5 \\
Duhok* & 8 & $<1 \%$ & $4 / 91$ \\
Duhok* & 34 & $1 \%$ & Ma5 \\
Duhok* & 13 & $8 \%$ & H120 \\
Duhok* & 15 & $2 \%$ & Unknown \\
\hline
\end{tabular}

*Center of Duhok province (Duhok subdistrict). 4/91 and H120 at first day, Ma5 at 8 days.

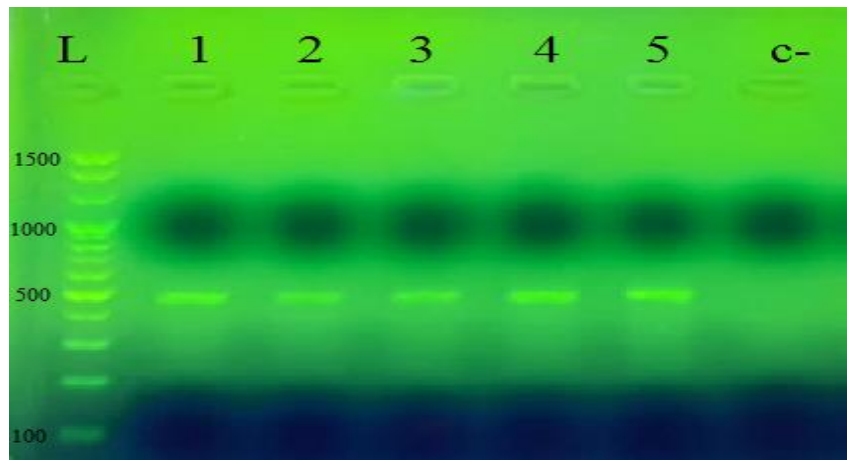

Figure 1: RT PCR for partial S1 gene of IBV from some of the collected samples in broiler fields. L: DNA Ladder (100+ bp); Lane 1-5 positive samples to IBV (464 bp); Lane c-: Negative control.

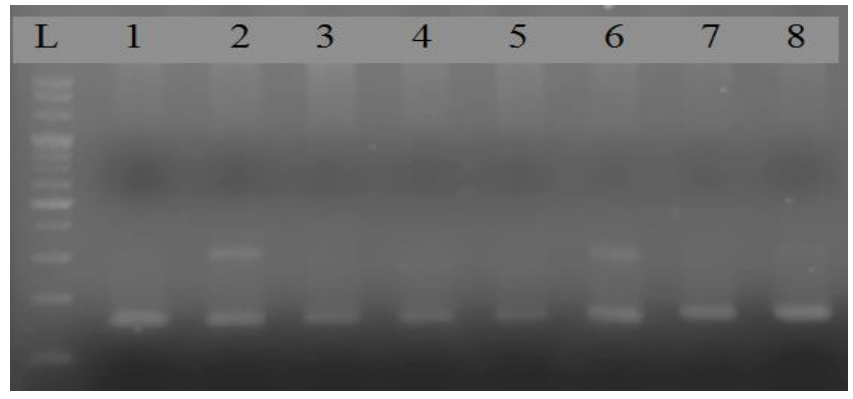

Figure 2: Nested PCR for partial S1 gene of Mass (295 bp) and 793/B (4/91) (154 bp) of IBV in the positive samples collected from broiler fields. Lane L: DNA ladder (100+ bp), Lane 1-8 positive samples to IBV.

\section{Discussion}

Infectious bronchitis disease is considered one of the most spread diseases among broiler fields in Iraq. This leads to massive economic losses in this sector. Protection from this disease is mainly dependent on vaccinating the birds with different strains from different origins in every production cycle $(12,15)$. However, the outbreaks still rising which may indicate the weakness of these vaccines in making enough protection. According to Jahantigh et al. (5) vaccination against IBV may fail in case of entering a new strain in a specific geographical region. Mahmood et al. (14) linked the low efficiency of vaccines used for IBV in Sulaimani province, North of Iraq to the presence of new strain Sul/01/09 (Genebank accession number: GQ281656).

Although continuous IBV cases are detectable in most of the broiler farms in Duhok province, there have been no reports on circulating IBV strains or genotyping of this virus in the area. RT-PCR and Nested PCR have been widely used in this concern due to their efficiency in the identification and genotyping of the isolated IBV and other infectious agents in the broiler and other animals (16-19). Therefore, this study was aimed to genotype the collected positive samples to IBV in the broiler fields in Duhok province, in Iraq. Positive results of PCR are an indication of widely spread of this disease among poultry farms in this area. Due to its sensitivity, the nested PCR technique is widely used to differentiate the obtained amplicons (20). Consequently, in this study, the published primers were able to amplify specified amplicons from 793/B (4/91) and Massachusetts types. Besides the usages of the 4/91 vaccine, the results indicated that all of the collected samples were infected with nephropathogenic strain with the detectable amplicon size that has been targeted with the used primers. Infection of broiler with the same vaccine strain may be due to administration of a vaccine to the IBVinfected chickens with IBV. An additional reason may be due to recombination between vaccine strains with field isolates shortly after vaccination or the use of multiple vaccine strains in the fields (21).

In two fields, the presence or coexistence of both strains Mass and 4/91 was observed. This may be to the same reasons which were mentioned above by Cavanagh (21). This phenomenon was detected by Nouri (22) when they found both Mass and 793/B (4/91) strains in 33 tested flocks. These authors claimed that there is no or poor crossprotection between these two vaccines against IBV. Infection with 4/91 in Duhok province is almost the same as that rate recorded in Sulaimani, Basra, Thi-Qar, and Muthana governorates $(14,23)$. Additionally, infection with Mass types was the same as the prevalence rate in mentioned provinces. Finally, the results showed that the virus can affect birds of all ages and this was concluded by Cavanagh and Al-Jameel and Al-Mahmood $(1,24)$. 


\section{Conclusion}

In our study genotyping of IBV by Nested PCR was investigated for the first time in Duhok province, north of Iraq. The results of this study indicate the presence of more than one strain of IBV in the broiler fields. Additionally, this technique was successful in amplifying and genotyping the targeted region of the $\mathrm{S} 1$ gene of IBV. Complete infection with 793/B (4/91) type of collected samples may indicate the poor vaccination programs against IBV in broiler fields. Co-infection with both strains may be due to low cross-protection among circulating and vaccine strains of IBV. We highly recommend further studies on sequence study of isolated IBV from broiler fields as well as efficient biosecurity and vaccination program against this virus in this area.

\section{Acknowledgment}

Special thanks to the Animal Production Department, College of Agricultural Engineering Sciences, University of Duhok for their continuous support. Great thanks and appreciation to Mr. Merkhan Mahdi Mustafa, New vet private veterinary clinic for his priceless help throughout the project.

\section{Conflict of interest}

The authors declare that there are no conflicts of interest regarding the publication of this manuscript.

\section{References}

1. Cavanagh D, Mawditt K, Welchman DB, Britton P, Gough RE. Coronaviruses from pheasants (Phasianus colchicus) are genetically closely related to coronaviruses of domestic fowl (infectious bronchitis virus) and turkeys. Avian Pathol. 2002;31:81-93. DOI: $\underline{10.1080 / 03079450120106651}$

2. de Wit JJ, Cook JK, Van Der Heijden HM. Infectious bronchitis virus variants: a review of the history, current situation and control measures. Avian Pathol. 2011;40:223-235. DOI: $\underline{10.1080 / 03079457.2011 .566260}$

3. Ignjatovic J, Ashton DF, Reece R, Scott P, Hooper P. Pathogenicity of Australian strains of avian infectious bronchitis virus. J Comp Pathol. 2002;126:115-123. 10.1053/jcpa.2001.0528

4. Ignjatovic J, Sapats S. Avian infectious bronchitis virus. Revue Scientifique et Technique-Office International des Epizooties. 2000;19:493-501. Doi: 10.20506/rst.19.2.1228

5. Jahantigh M, Salari S, Hedayati M. Detection of infectious bronchitis virus serotypes by reverse transcription polymerase chain reaction in broiler chickens. Springer Plus. 2013;2:1-4. 10.1186/2193-1801-2-36

6. Setiawaty R, Soejoedono RD, Poetri ON. Genetic characterization of S1 gene of infectious bronchitis virus isolated from commercial poultry flocks in West Java, Indonesia. Vet World. 2019;12:231-235. DOI: 10.14202/vetworld.2019.231-235

7. Alvarado IR, Villegas P, Mossos N, Jackwood MW. Molecular characterization of avian infectious bronchitis virus strains isolated in
Colombia during 2003. Avian Dis. 2005;49:494-499. 10.1637/7202050304R.1

8. Lee CW, Hilt DA, Jackwood MW. Identification and analysis of the Georgia 98 serotype, a new serotype of infectious bronchitis virus. Avian Dis. 2001;45:164-172. 10.2307/1593024

9. Cavanagh D. Severe acute respiratory syndrome vaccine development: experiences of vaccination against avian infectious bronchitis coronavirus. Avian Pathol. 2003;32:567-582. 10.1080/03079450310001621198

10. Abass HA. A study of infectious bronchitis in chicken [master's thesis]. Baghdad: College of Veterinary Medicine, Baghdad University, Iraq; 2000.

11. Azab AJ, Basher HA, Hassan SM. Infectious bronchitis in broiler chicken in Iraq. Isolation and identification of the insolent (AM 88). Indian J Vet Med. 1989;9:104-107. [available at]

12. Seger W, Ghalyanchilangeroudi A, Karimi V, Madadgar O, Marandi MV, Hashemzadeh M. Prevalence of avian infectious bronchitis virus in broiler chicken farms in south of Iraq, 2014 - 2015. Vet Res Forum. 2016;7:317-321. [available at]

13. Atta RN, Allawe AB. Isolation and sequencing of field isolates of Avian infectious bronchitis virus in Iraq. J Entomol Zool Stud. 2018;6:529-540. [available at]

14. Mahmood ZH, Sleman RR, Uthman AU. Isolation and molecular characterization of Sul/01/09 avian infectious bronchitis virus, indicates the emergence of a new genotype in the Middle East. Vet Microbiol. 2011;150:21-27. DOI: 10.1016/j.vetmic.2010.12.015

15. Isa RH, Abdo JM, AL-barzinji YMS. Diagnosis of coronavirus by Real-Time PCR in broiler fields in Duhok governorate, Iraq. J Duhok Uni. 2020;23:45-50. 10.26682/ajuod.2020.23.1.6

16. Cavanagh D, Mawditt K, Britton P, Naylor CJ. Longitudinal field studies of infectious bronchitis virus and avian pneumovirus in broilers using type-specific polymerase chain reactions. Avian Pathol. 1999;28:593-605. DOI: 10.1080/03079459994399

17. Jarad NI. Molecular detection of Cryptosporidium parvum in chicken in Al-Diwaniya province. Iraqi J Vet Sci. 2020;34: 441-445. DOI: 10.33899/ijvs.2019.126159.1249

18. Naser HH. The genotype of Entamoeba histolytica in bloody diarrhoea samples of humans, cows and sheep. Iraqi $\mathrm{J}$ Vet Sci. 2020;34:453-458. DOI: $10.33899 /$ ijvs.2020.126135.1242

19. Isihak FA, Ismail HK, Wahid AA. Diagnosis and histopathological study of avian influenza virus-H5 (AIV-H5) in broiler farms. Iraqi J Vet Sci. 2020;34:101-107. DOI: 10.33899/ijvs.2019.125646.1120

20. Adzhar A, Gough RE, Haydon D, Shaw K, Britton P, Cavanagh D. Molecular analysis of the 793/B serotype of infectious bronchitis virus in Great Britain. Avian Path. 1997;26:625-640. 10.1080/03079459708419239

21. Cavanagh D. Coronavirus avian infectious bronchitis virus. Vet Res. 2007;3:281-297. DOI: $10.1051 /$ vetres:2006055

22. Nouri A, Assasi K, Seyfi-abad Shapouri MR. Field study of infectious bronchitis virus in broiler using type-specific RT-PCR. Arch Razi Ins. 2003;55:1-10. DOI: 10.22092/ARI.2003.109034

23. Seger W, Ghalyanchi LA, Karimi V, Madadgar O, Marandi MV, Hashemzadeh M. Genotyping of infectious bronchitis viruses from broiler farms in Iraq during 2014-2015. Arch Virol. 2016;161:12291237. DOI: $10.1007 / \mathrm{s} 00705-016-2790-2$

24. Al-Jameel W, Al-Mahmood SS. Similarities and differences of COVID-19 and avian infectious bronchitis from molecular pathologist and poultry specialist view point. Iraqi J Vet Sci. 2020;34:223-231. DOI: $10.33899 /$ ijvs.2020.126984.1426 
اقتصادية فادحة في كل وجبة من وجبات الإنتاج. بالرغم من أستخدم

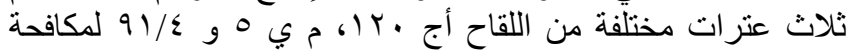

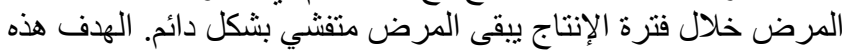

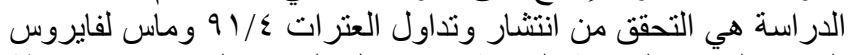

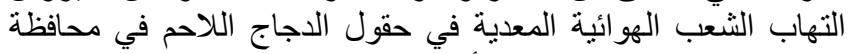

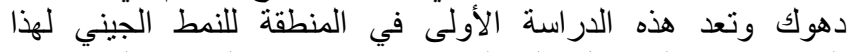

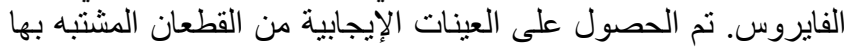

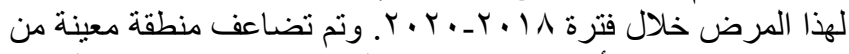

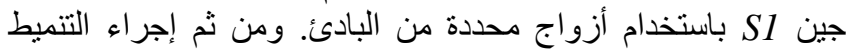

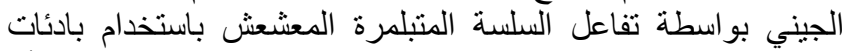

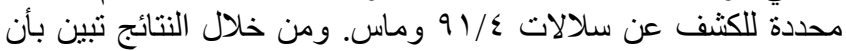

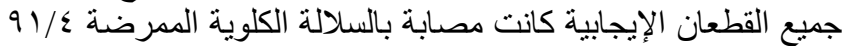

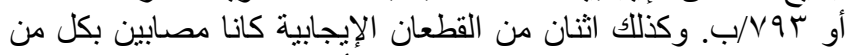

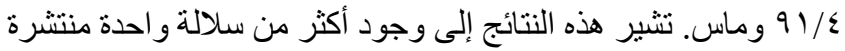
في المنطقة وكذلك تظهر ضعف اللقاحات المستخدمة في حقول الدجاج الناج

\section{النمط الجيني لفايروس التهاب الثعب الهوائية

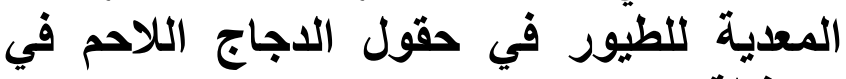

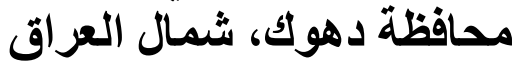

ريناس حسين عيسى'، جاسم محمد عبدو و يوسف محمد صالح البرزنجي آنين

'قسم الإنتاج الحيواني، كلية علوم الهندسة الزراعية، جامعة دهوك،

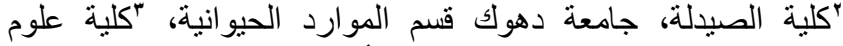
الهندسة الزر اعية، جامعة صلاح الدين، أربيل، العراق

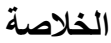

أصبح مرض التهاب الثعب الهو ائية المعدي أكثر الأمر اض تحديا

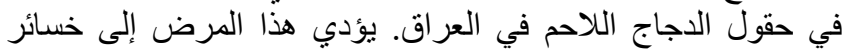

